Article

\title{
Tracking the Detrital Zircon Provenance of Early Miocene Sediments in the Continental Shelf of the Northwestern South China Sea
}

\author{
Ce Wang ${ }^{1,2,3}$, Letian Zeng ${ }^{1,2,3}$, Yaping Lei ${ }^{1,2,3}$, Ming Su ${ }^{1,2,3, *}$ and Xinquan Liang ${ }^{4}$ \\ 1 School of Marine Sciences, Sun Yat-sen University, Zhuhai 519082, China; wangce@mail.sysu.edu.cn (C.W.); \\ zenglt5@mail2.sysu.edu.cn (L.Z.); eeslyp@mail.sysu.edu.cn (Y.L.) \\ 2 Southern Marine Science and Engineering Guangdong Laboratory (Zhuhai), Zhuhai 519080, China \\ 3 Guangdong Provincial Key Laboratory of Marine Resources and Coastal Engineering, \\ Guangzhou 510006, China \\ 4 State Key Laboratory of Isotope Geochemistry, Guangzhou Institute of Geochemistry, Chinese Academy of \\ Sciences, Guangzhou 510640, China; liangxq@gig.ac.cn \\ * Correspondence: suming3@mail.sysu.edu.cn
}

Received: 7 July 2020; Accepted: 22 August 2020; Published: 25 August 2020

\begin{abstract}
Sediment provenance studies have become a major theme for source-to-sink systems and provide an important tool for assessing paleogeographic reconstruction, characterizing the depositional system, and predicting reservoir quality. The lower Miocene is an important stratigraphic unit for deciphering sediment evolution in the continental shelf of the northwestern South China Sea, but the provenance characteristics of this strata remain unclear. In this study, detrital zircon U-Pb geochronology and Lu-Hf isotopes from the lower Miocene Sanya Formation in the Yinggehai-Song Hong Basin were examined to study the provenance and its variation in the early Miocene. U-Pb dating of detrital zircons yielded ages ranging from Archean to Cenozoic (3313 to $39 \mathrm{Ma}$ ) and displayed age distributions with multiple peaks and a wide range of $\varepsilon_{\mathrm{Hf}}(\mathrm{t})$ values (from -27.2 to +8.5 ). Multi-proxy sediment provenance analysis indicates that the Red River system was the major source for the sediments in the northern basin, with additional contribution from central Vietnam, and the Hainan played the most important role in contributing detritus to the eastern margin of the basin in the middle Miocene. This paper highlights the provenance of early Miocene sediments and contributes to paleogeographic reconstruction and reservoir evaluation.
\end{abstract}

Keywords: provenance; detrital zircon; Lu-Hf isotopes; early Miocene; Yinggehai-Song Hong Basin; South China Sea

\section{Introduction}

Tracing sediment delivery from terrigenous sources to oceanic sinks is crucial for understanding the sedimentary process at ocean margins. Clastic sedimentary rocks contain key information relating to their provenance and the sedimentary process and can therefore be used to reveal source-to-sink systems during deposition [1-3]. The provenance study of sediments provides an important tool for assessing paleogeographic reconstruction, characterizing the depositional system, and predicting reservoir quality $[4,5]$. Sediment provenance studies have become a major theme for source-to-sink studies and have promoted efforts to link terrestrial and marine segments via the sediments produced, transported, and deposited within systems [6-8]. Over the last decades, geochronology applied to detrital minerals, such as zircon, apatite, monazite, rutile, and titanite, have received increased attention for their ability to provide insight into provenance, erosion, and tectonic processes $[9,10]$. 
Zircon has received considerable attention for its stability and has many uses within earth science systems, as zircon can withstand the effects of weathering, erosion, and thermal alteration during transportation, deposition, and diagenesis. U-Pb geochronology of detrital zircon is a robust tool that has been widely used to evaluate sediment provenance, tectonics, climate, and source-to-sink processes in margins [11]. In addition, studies of Lu-Hf isotopic compositions in detrital zircon are another distinctive feature of zircon other than $\mathrm{U}-\mathrm{Pb}$ age. Their use can make source identification more robust [12].

The Yinggehai-Song Hong (Y-SH) Basin, which is located on the continental shelf of the northwestern South China Sea (Figure 1) and was formed at the southeastern termination of the Red River Fault in the Cenozoic era, is one of the most gas-rich sedimentary basins in this region. The marine sediments in this region provide an important case for understanding the provenance and transport processes from terrigenous source to oceanic sink. Over the last decade, diverse methods have been used to study the provenance of sediments, ranging from detrital minerals, geochemistry, seismic data, and isotopes to geochronology in the basin [13-18]. The provenance studies have been conducted using an integrated approach, which allows us to quantitatively assess the contributions of different potential source terranes of the Red River, central Vietnam, and Hainan Island (Figure 1). Most provenance studies in the northwestern shelf of the South China Sea have been focused on the middle Miocene to Quaternary sediments; by contrast, only a few studies have examined the lower Miocene and underlying strata. The lower Miocene Sanya Formation is an important potential reservoir in the Y-SH Basin [19]. The understanding of sediment provenance of Sanya Formation and its transport pathway is a key point to reconstruct the paleogeography and establish the reservoir presence in clastic petroleum systems of the basin. However, up to now, the provenance of this stratigraphic unit was not well investigated, and a more effective method should be conducted to reveal the provenance of sediments.

The amount of zircon $\mathrm{U}-\mathrm{Pb}$ geochronological data around the northwestern margin of the South China Sea has substantially increased over the last decades [17,20-22]. For instance, Hoang et al. (2009) [23] used the U-Pb dating and Hf isotopic analysis of detrital zircons from Red River sands in order to constrain the provenance of the modern river and to decipher drainage evolution through time. $\mathrm{U}-\mathrm{Pb}$ dating of detrital zircon along the main drainage systems in the western Hainan was carried out by Wang et al. (2015) [24] with aims to reveal the provenance and tectonic evolution of Hainan Island. Jonell et al. (2017) [25] used multiple geochemical datasets, including the detrital zircon U-Pb geochronology from the Gianh River in the central Vietnam, to understand the sediment transport and erosion patterns of the eastern Indochina Block. Wang et al. (2018) [20] and Fyhn et al. (2019) [17] investigated the detrital zircon geochronology of each source terranes around the Y-SH Basin and identified the differences in the age composition of detrital zircons. This abundance of comparative data for each source terrane makes the detrital zircon method especially suitable for provenance study in the region. Here, a new set of detrital zircon $\mathrm{U}-\mathrm{Pb}$ dating and $\mathrm{Lu}-\mathrm{Hf}$ isotopes from the lower Miocene Sanyan Formation in the Y-SH Basin was used to study the sediment provenance of early Miocene sediments, elucidate the spatial and temporal variation in provenance, and understand the source-to-sink process in the northwestern margin of the South China Sea. 


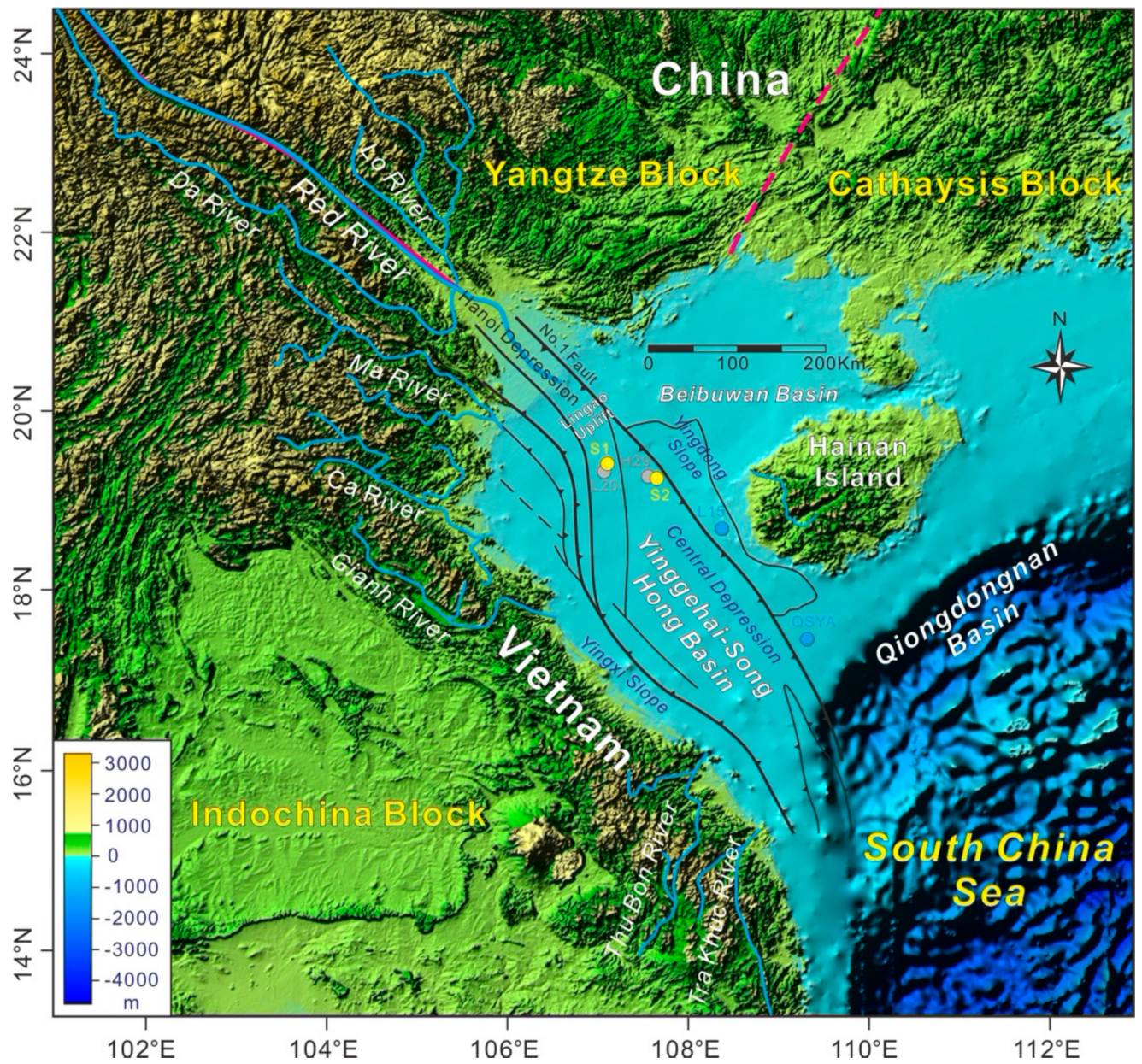

Figure 1. Topographic map and major drainage systems around the Yinggehai-Song Hong Basin. Yellow dots indicate the borehole locations in this study. Borehole locations of samples QSYA and L15 are from Yan et al. (2011) [13] and Wang et al. (2019) [26], respectively. Borehole locations of L20 and H29 are from Wang et al. (2016) [27].

\section{Materials and Methods}

Two sedimentary samples (S1-1 and S2-1) of the Sanya Formation in this study were collected from two boreholes that were drilled by the China National Offshore Oil Corporation in the Y-SH Basin (Figure 1). The primary strata boundaries can be effectively marked from the analysis and correlation of seismic sequences and nanofossil biostratigraphy. Samples S1-1 and S2-1 were obtained from the boreholes at depths of $3400 \mathrm{~m}$ and $3618 \mathrm{~m}$, respectively. One published sample (L15-1) with dated zircon U-Pb ages by Wang et al. (2019) [26] was used only for Lu-Hf isotopic analyses. The selected samples are core chips and are fine- to medium-grained sandstone.

The zircons were separated from these two samples using conventional heavy liquids and magnetic separation techniques. After hand sorting using the binocular stereoscope, the zircon grains were mounted in transparent epoxy and polished down to approximately half sections. The internal structures of zircons were examined using cathodoluminescence (CL) images taken by a Mono CL3 detector attached to an electron microprobe (JXA-8100, JEOL, Tokyo, Japan) attached to an electron microprobe. The analytical spots without inclusions and fractures were selected according to the CL images. Zircon grains were randomly picked from the selected spots for laser ablation analyses.

The zircons were dated using laser ablation inductively coupled plasma mass spectrometry (LA-ICP-MS) at the Guangzhou Institute of Geochemistry, Chinese Academy of Sciences. Sample mounts were placed in the two-volume sample cell flushed with Argon and Helium. 
Laser ablation was performed at a constant energy of $80 \mathrm{~mJ}$ and at $8 \mathrm{~Hz}$, with a spot diameter of $31 \mu \mathrm{m}$. The ablated ions were carried by Helium to the Agilent 7500a ICP-MS (Agilent Technologies, Santa Clara, CA, USA). Isotopic ratios of U-Th-Pb were calculated by software of ICPMSDataCal (Version 11.0) [28]. The details of precision, accuracy, and analytical procedure are described by Zhang et al. (2018) [29]. Common Pb was corrected by ComPbCorr\#3_151 using the method of Andersen (2002) [30]. ${ }^{206} \mathrm{~Pb} /{ }^{238} \mathrm{U}$ ages of less than $1000 \mathrm{Ma}$ were used, and ${ }^{207} \mathrm{~Pb} /{ }^{206} \mathrm{~Pb}$ ages were selected if the ${ }^{206} \mathrm{~Pb} /{ }^{238} \mathrm{U}$ ages were more than $1000 \mathrm{Ma}$.

Zircon Lu-Hf isotopic analyses were carried out on a Neptune Plus multi-collector ICP-MS (Thermo Scientific, Bremen, Germany) equipped with a RESOlution M-50 laser-ablation system (Resonetics, Nashua, NH, USA) at the same institute. The Lu-Hf isotopic measurements were made on the same spots previously analyzed for $\mathrm{U}-\mathrm{Pb}$ isotopes. The laser parameters were as follows: spot size, $45 \mu \mathrm{m}$; repetition rate, $8 \mathrm{~Hz}$; energy, $80 \mathrm{~mJ}$. Helium was used as a carrier gas and a small flow of nitrogen was added to the gas line to enhance the sample signal. ${ }^{173} \mathrm{Yb}$ and ${ }^{175} \mathrm{Lu}$ were used to correct the isobaric interference of ${ }^{176} \mathrm{Yb}$ and ${ }^{176} \mathrm{Lu}$ on ${ }^{176} \mathrm{Hf}$. The ${ }^{176} \mathrm{Hf} /{ }^{177} \mathrm{Hf}$ was normalized to ${ }^{179} \mathrm{Hf} /{ }^{177} \mathrm{Hf}=0.7325$ using an exponential law for mass bias correction. The initial Hf isotope ratios were denoted as $\varepsilon_{\mathrm{Hf}}(\mathrm{t})$ values that were calculated with the chondritic uniform reservoir (CHUR) at the time of zircon crystallization, and the present-day ${ }^{176} \mathrm{Hf} /{ }^{177} \mathrm{Hf}$ and ${ }^{176} \mathrm{Lu} /{ }^{177} \mathrm{Hf}$ ratios of chondrite and depleted mantle were at 0.28277 and $0.0332,0.28325$, and 0.0384 , respectively [31]. Initial ${ }^{176} \mathrm{Hf} /{ }^{177} \mathrm{Hf}$ values were calculated based on a ${ }^{176} \mathrm{Lu}$ decay constant of $1.865 \times 10^{-11}$ year ${ }^{-1}$ [32]. Two-stage model Hf ages $\left(\mathrm{T}_{\mathrm{DM} 2}\right)$ were computed using a ${ }^{176} \mathrm{Lu} /{ }^{177} \mathrm{Hf}$ value of 0.015 for the average continental crust [33].

\section{Results}

A total of 170 zircon analyses were performed using LA-ICP-MS. The U-Pb concordia diagrams and CL images of the representative zircons are shown in Figure 2. Most of the zircon grains were colorless to transparent, with a wide range of prismatic to oval-shaped crystals. The morphologies of the zircon grains were distinctive for early Miocene sediments. Samples S1-1 and S2-1 were mostly concentrated in the range of 70-150 $\mu \mathrm{m}$, and most of them had sub-rounded or rounded corners, which generally implied prolonged or multi-cycle transport. By contrast, most zircons from the sediments near Hainan offshore (L15-1, Figure 1) were complete crystals without obvious rounded corners [26], suggestive of proximal transport.
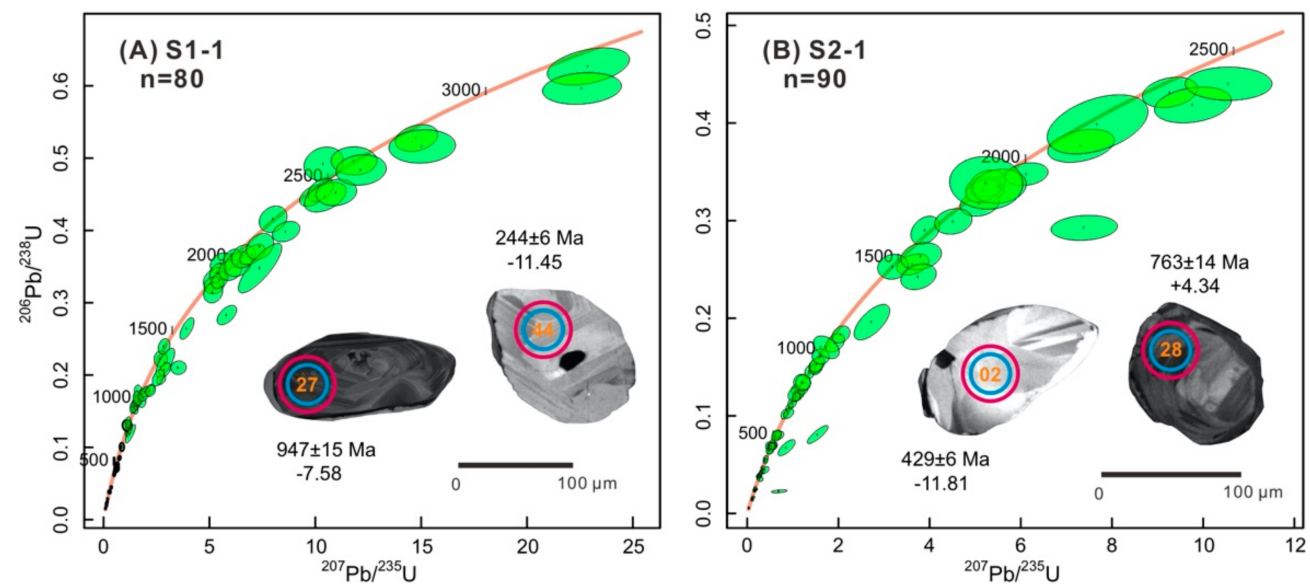

Figure 2. U-Pb concordia diagrams and representative $\mathrm{CL}$ images for zircons from the lower Miocene sediments. IsoplotR was used for concordia diagrams [34]. The small and large circles denote the analytical spots for U-Pb ages and Lu-Hf isotopes, respectively. Numbers near the circles are U-Pb ages and the corresponding $\varepsilon_{\mathrm{Hf}}(\mathrm{t})$ values.

The original $\mathrm{U}-\mathrm{Pb}$ isotopic data of the zircon grains are shown in Table S1. Discordances smaller than $10 \%$ were considered in this study. The samples varied greatly in Th/U values, ranging from 0.05 
to 3.77, and only four spots were less than 0.1 (Figure 3). Compared with the age probability model, kernel density estimators (KDEs) were more robust for displaying age populations and peak ages [35]. KDEs were used for displaying age populations and the ages of peaks (Figure 4). The Lu-Hf isotopic results for the detrital zircons are provided in Table S2 and are illustrated in Figure 5.
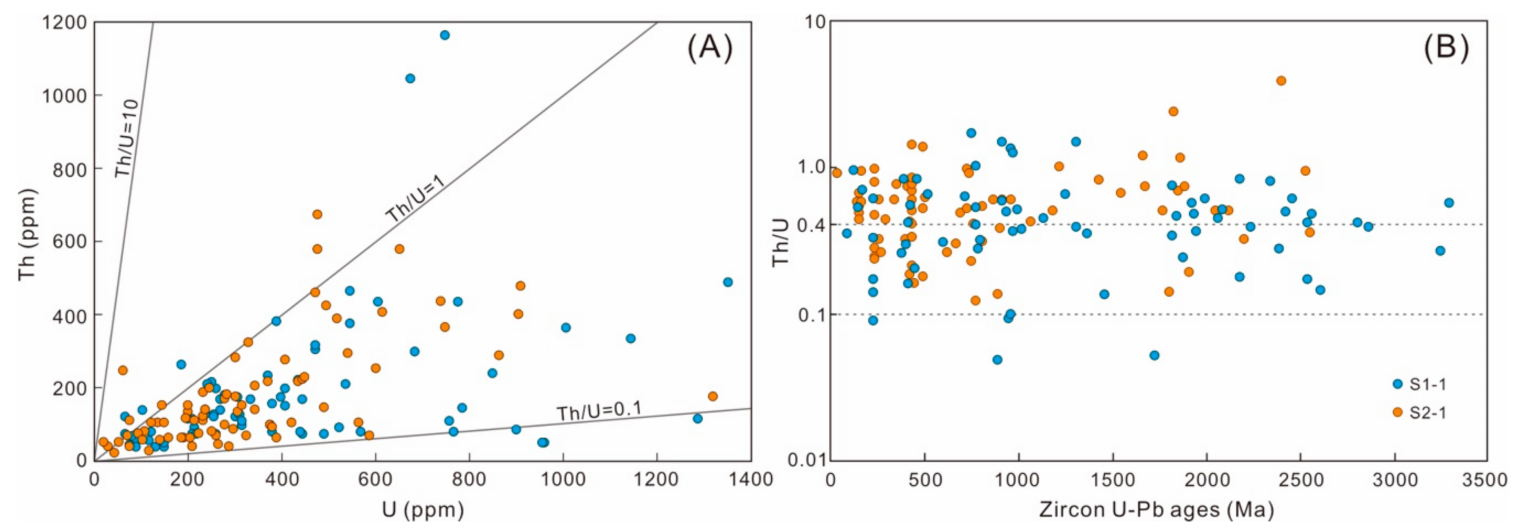

Figure 3. (A) Th versus $\mathrm{U}$ and (B) Th/U versus $\mathrm{U}-\mathrm{Pb}$ diagrams for the concordant zircons from the S1-1 and S2-1 samples in the Yinggehai-Song Hong Basin.

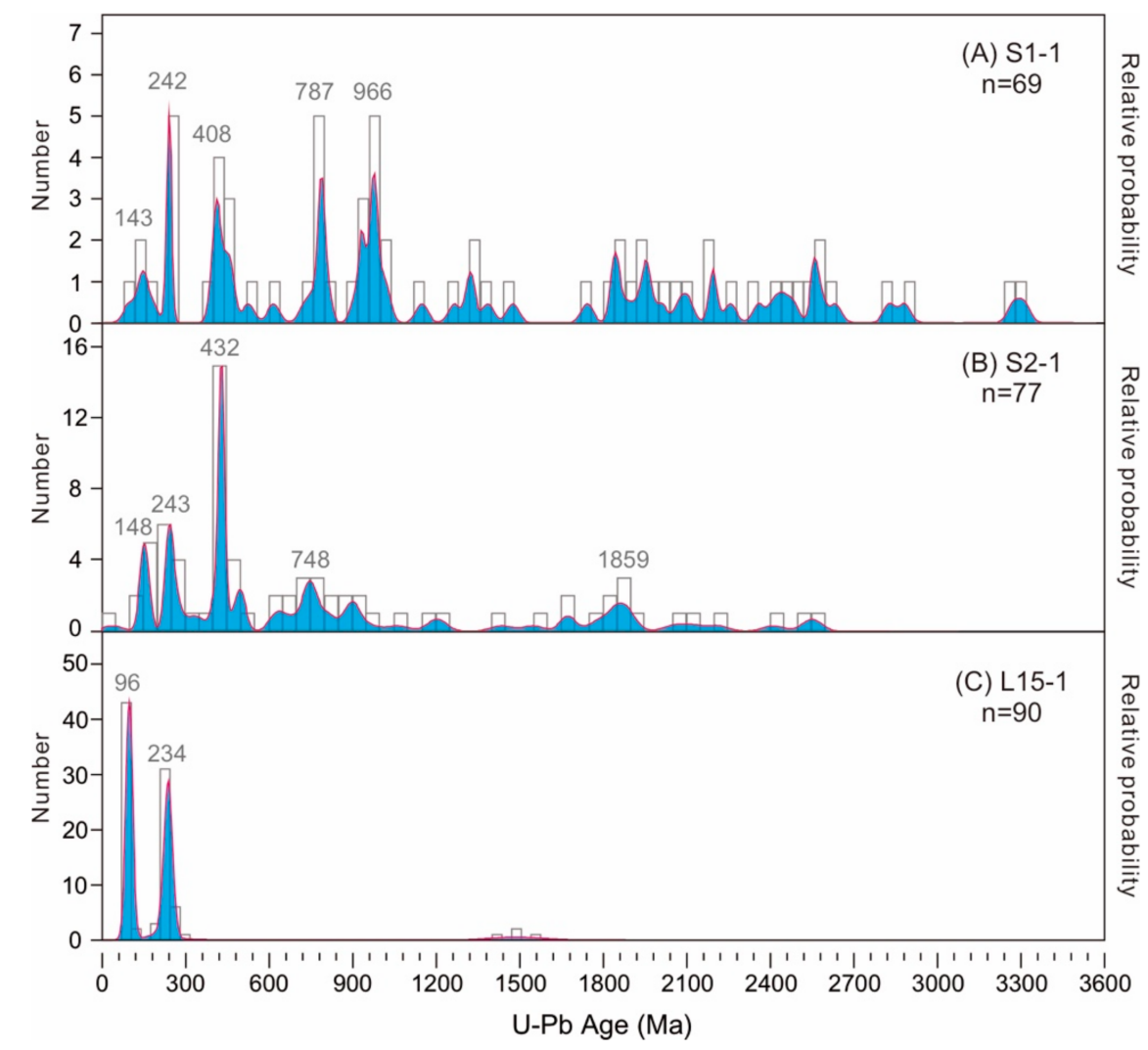

Figure 4. Kernel density estimation plots of detrital zircon U-Pb ages from the lower Miocene sediments in the Yinggehai-Song Hong Basin (A-C). The data of sample L15-1 was collected from Wang et al. (2019) [26].

\subsection{Sample $S 1$}

Most of the zircon grains in sample S1 showed obvious oscillatory growth zoning under CL (Figure 2), along with Th/U values greater than 0.4 (Figure 3), suggesting that they have a magmatic origin [36]. In addition, only four zircons had a Th/U ratio smaller than 0.1 (Figure 3), implying a 
potential metamorphic origin only for these few grains. A total of 80 zircon grains were analyzed, and 69 concordant ages were obtained for the sample. Measured $\mathrm{U}-\mathrm{Pb}$ ages ranged from $3313.3 \mathrm{Ma}$ to 99.6 Ma (Table S1). The concordant zircons showed five major age peaks at ca. $143 \mathrm{Ma}, 242 \mathrm{Ma}, 408 \mathrm{Ma}$, $787 \mathrm{Ma}$, and $966 \mathrm{Ma}$ (Figure 4A).

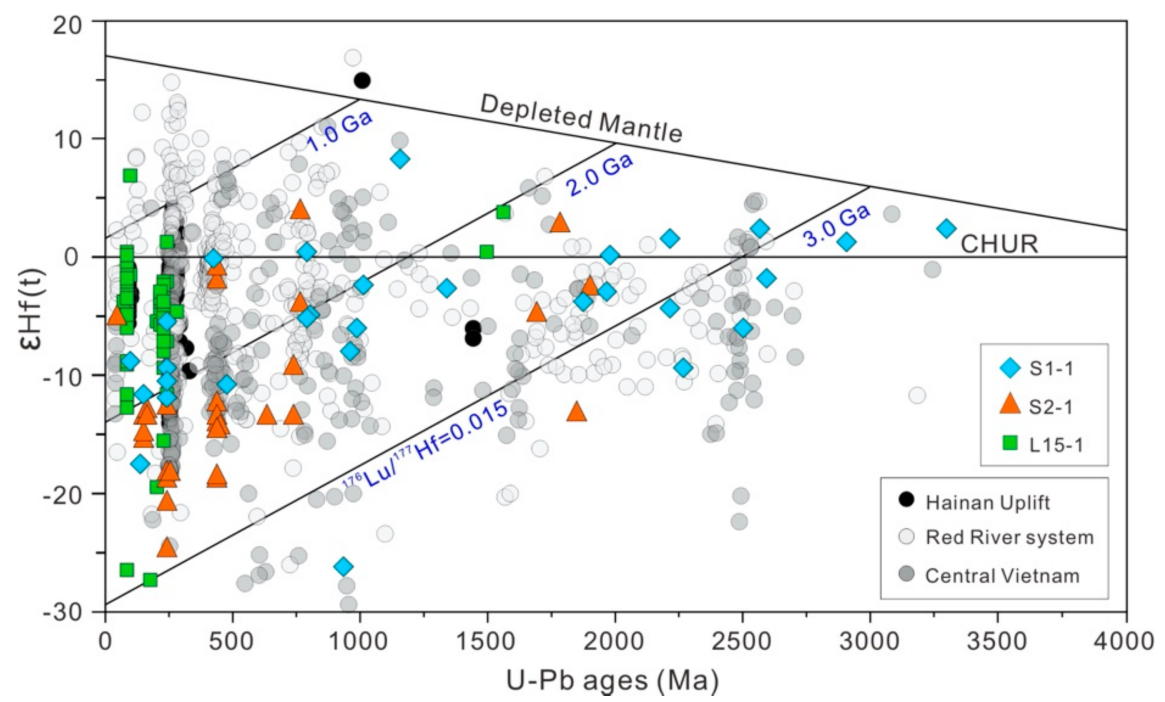

Figure 5. Diagrams showing the relationships between $\varepsilon_{\mathrm{Hf}}(\mathrm{t})$ values and zircon U-Pb ages. The data of Red River and rivers in central Vietnam are from Wang et al. (2018) [20] and references therein. The data of bedrock in Hainan Uplift are from Wen (2013) [37], Wen et al. (2013) [38] and Sun et al. (2018) [39]. CHUR: chondritic uniform reservoir.

Twenty-nine dated zircon grains from sample S1 were selected for Lu-Hf isotope analysis. The analysis revealed a broad range of ${ }^{176} \mathrm{Hf} /{ }^{177} \mathrm{Hf}$ ratios from 0.280773 to 0.282527 , with $\varepsilon_{\mathrm{Hf}}(\mathrm{t})$ values from -25.7 to +8.5 (Figure 5). The two-stage Hf isotopic model ages $\left(\mathrm{T}_{\mathrm{DM} 2}\right)$ for these zircons ranged from 3414 to 1184 Ma (Table S2).

\subsection{Sample S2}

The crystals were euhedral with partially round corners for most zircon grains (Figure 2). These zircons showed oscillatory growth zoning under CL (Figure 2). A total of 90 zircon grains were analyzed, and 77 concordant ages were obtained for the sample. The Th/U ratios of the zircons ranged from 0.12 to 3.77 and were concentrated in the range of 0.5-0.7 (Table S1), indicating that these zircons were magmatic in origin. Measured U-Pb ages showed a wide age span ranging from 2564.8 to $38.8 \mathrm{Ma}$ (Table S1). The concordant zircons displayed five major age peaks at ca. $148 \mathrm{Ma}, 243 \mathrm{Ma}, 432 \mathrm{Ma}$, $748 \mathrm{Ma}$, and $1859 \mathrm{Ma}$ (Figure 4B).

Thirty-one dated zircon grains from the sample were selected for Lu-Hf isotope analysis. The analysis revealed a range of ${ }^{176} \mathrm{Hf} /{ }^{177} \mathrm{Hf}$ ratios from 0.281269 to 0.282621 , with $\varepsilon_{\mathrm{Hf}}(\mathrm{t})$ values from -24.1 to +4.3 (Figure 5 ). The two-stage Hf isotopic model ages $\left(\mathrm{T}_{\mathrm{DM} 2}\right)$ for these zircons ranged from 2988 to 1102 Ma (Table S2).

\subsection{Sample L15-1}

The detrital zircon $\mathrm{U}-\mathrm{Pb}$ geochronological data of this sample were described in detail by Wang et al. (2019) [26]. This sample had two major age peaks at ca. 96 and 234 Ma (Figure 4C). Sixty dated zircon grains from the sample were selected for $\mathrm{Lu}-\mathrm{Hf}$ isotope analysis. The analysis revealed a range of ${ }^{176} \mathrm{Hf} /{ }^{177} \mathrm{Hf}$ ratios from 0.281872 to 0.282901 , with $\varepsilon_{\mathrm{Hf}}(\mathrm{t})$ values from -27.2 to +6.8 (Figure 5). The two-stage Hf isotopic model ages $\left(\mathrm{T}_{\mathrm{DM} 2}\right)$ for these zircons ranged from 2338 to $596 \mathrm{Ma}$ (Table S2). 


\section{Discussion}

\subsection{Potential Source Characteristics of the Sediments}

Previous studies have suggested three potential source terranes for the Y-SH Basin fill, including the Red River source (Southern Yangtze Block), central Vietnam (Eastern Indochina Block), and the Hainan Uplift $[13,14]$. These sources have completely different tectonic-magmatic evolutions and have produced zircons with distinct age spectra, which can be illustrated by the age distributions of the bedrock and modern drainage systems (Figure 6).
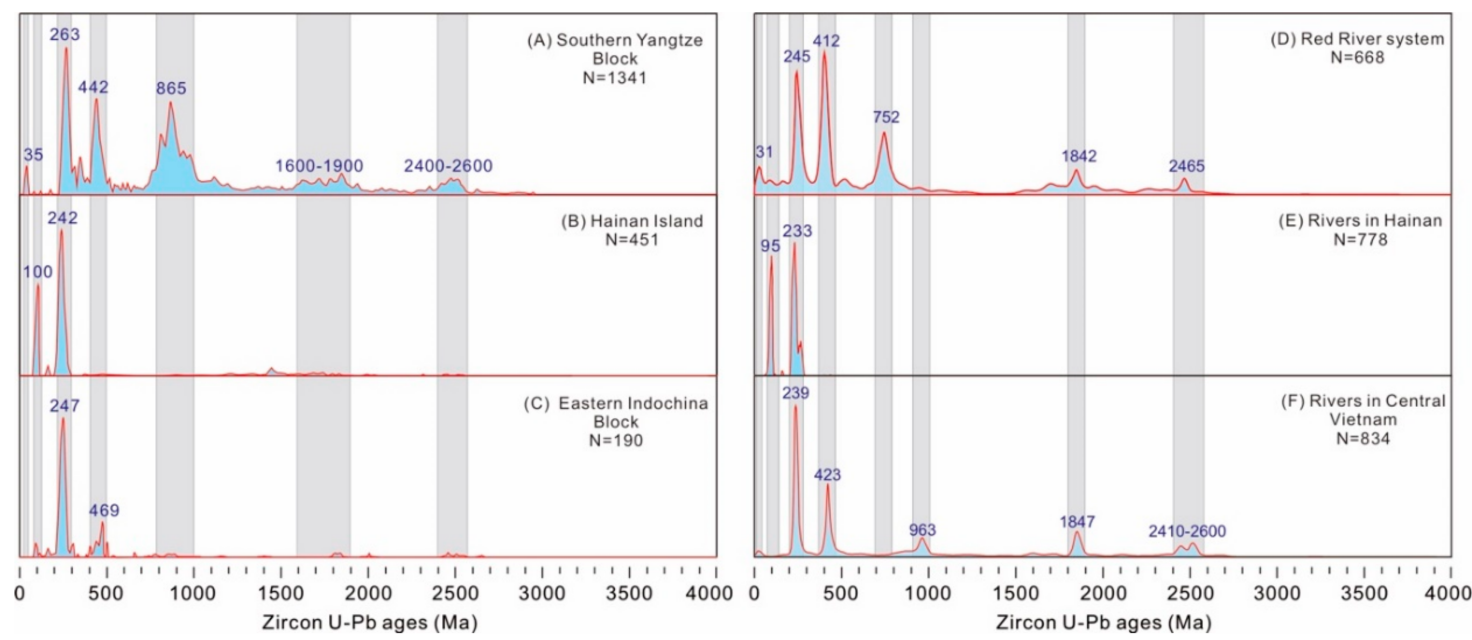

Figure 6. Summary of zircon $\mathrm{U}-\mathrm{Pb}$ ages of the potential sources $(\mathrm{A}-\mathrm{C})$ and drainage systems discharge to the Yinggehai-Song Hong Basin (D-F). The original data of basement rocks of the potential sources were compiled by Wang et al. (2018) [21] and references therein. The data for the Red River and drainage systems in Central Vietnam are from Jonell et al., (2018) [25] and Wang et al. (2018) [20]. The data for the drainage systems in Hainan Uplift are from Cao et al. (2015) [22] and Wang et al. (2015) [24].

The Yangtze Block is an important component of the South China Block, which is separated from the Indochina Block by the Song Ma suture to the south and bounded by the Cathaysia Block to the east (Figure 1). Compared with the Hainan and eastern Indochina Block, the bedrock of the southern Yangtze Block displays a wide $\mathrm{U}-\mathrm{Pb}$ age distribution, with multiple peaks from the Archean to Cenozoic (Figure 6A). The Archean age population of 2600-2400 Ma accounts for a small portion of the total, which was confirmed to be the basement of the Yangtze Block [40]. The Paleoproterozoic age range from 1900 to $1600 \mathrm{Ma}$ was consistent with the ages for the coeval granitoids and sedimentary rocks in the Yangtze Block [41], such as the granites in the Kongling terrain, which yielded a U-Pb age of ca. $1850 \mathrm{Ma}$ [42]. Ages around $865 \mathrm{Ma}$ are related to the middle Neoproterozoic magmatic rocks and are widespread in the Yangtze Block [43]. Previous studies have shown that ca. 830-820 Ma granites can be found in the southeastern Yangtze Block [44]. The age peaks of 442 and 263 Ma are associated with the Late Paleozoic and Permian-Triassic tectonic-thermal events, respectively, which produced large amounts of igneous and metamorphic rocks. Cenozoic zircon ages ranging from 60 to 20 Ma have been reported from intrusions along the Red River Fault Zone [27,45]. The age peak of $35 \mathrm{Ma}$ might represent an important signature for igneous activity associated with the fault zone [14]. The modern Red River system displays a similar age feature with the bedrock in the southern Yangtze Block but also shows different age peaks, potentially suggesting that there is a small difference in provenance (Figure 6A,D). The Red River system displays a wide range of $\varepsilon_{\mathrm{Hf}}(\mathrm{t})$ values in different age populations (Figure 5). The Phanerozoic zircons with significant positive $\varepsilon_{\mathrm{Hf}}(\mathrm{t})$ values suggests that the protolith was formed in part from the juvenile component. In addition, the Precambrian zircons generally had negative $\varepsilon_{\mathrm{Hf}}(\mathrm{t})$ values, indicating that they were formed mainly by remelting of truly ancient crust. 
The Hainan Uplift is located on the southern margin of the Cathaysia Block. Mesoproterozoic granitic rocks have been discovered isolated in the island's west with zircon U-Pb ages of 1460-1400 [46,47], which can also be found in modern rivers in western Hainan [24]. Hainan is characterized by widespread Permian to Triassic granitoids with a range of dated zircon $\mathrm{U}-\mathrm{Pb}$ ages from 280 to $220 \mathrm{Ma}$ [38], yielding a dominant age peak at ca. 242 Ma (Figure 6B). Cretaceous granitic and volcanic rocks with age peaks of ca. $100 \mathrm{Ma}$ are primarily distributed in southwestern Hainan [39,48]. Both bedrock and modern rivers in Hainan show relatively simple age structures and are characterized by two age populations of 100-95 and 242-233 Ma (Figure 6B,E, respectively). Compared to the Red River and central Vietnam, the Hainan source shows relatively narrow $\varepsilon_{\mathrm{Hf}}(\mathrm{t})$ values for the Triassic to Cretaceous zircons (Figure 5).

Central Vietnam, which is located in the eastern Indochina Block, is characterized by Paleozoic to Mesozoic granitic and metamorphic rocks [49,50]. Recent studies have shown that the Ordovician-Silurian and Permian-Late Triassic magmatic activities in the Truong Son Belt and Kontum Massif have ages of 470-420 and 300-200 Ma, respectively [49,51-53]. The summarized geochronological data of the bedrock showed two major age peaks at ca. 247 and $469 \mathrm{Ma}$ (Figure 6C). Compared with the bedrock, the drainage systems in central Vietnam show a relatively complicated age structure, which was reflected by multiple peaks at ca. 2600-2410 Ma, $1847 \mathrm{Ma}, 963 \mathrm{Ma}, 423 \mathrm{Ma}$, and $239 \mathrm{Ma}$ (Figure 6F). Although the Hf isotopic composition of zircons in the central Vietnam is overlapped by counterparts from the source of Red River, the Phanerozoic zircons with more negative values (Figure 5) indicates that the protolith was formed primarily by an ancient crustal component.

\subsection{Provenance of the Detrital Zircons}

The detrital zircon age distributions of the two cored samples from the lower Miocene Sanya Formation form multiple peaks, which may be characteristic of the age signatures of specific bedrock and drainage systems around the basin.

Only one dated zircon was of Cenozoic age ( $38.8 \mathrm{Ma}$ ) in sample S2-1, with the $\varepsilon_{\mathrm{Hf}}(\mathrm{t})$ value of -4.5 . Although Cenozoic zircons have been widely reported in the Red River Fault Zone, they are practically absent from our sampling; however, this can be distinctively tied to that distal area. Zircon age was consistent with the Cenozoic granitic and metamorphic rocks in the fault zone [45,54], suggesting that these zircons may be derived from the southwestern margin of the Yangtze Block through the Red River system [14].

Samples S1-1 and S2-1 had Late Jurassic age peaks at ca. 143 and 148 Ma, respectively, ages consistent with the widespread Yanshanian granitoids in the South China Block [55], implying a source from the hinterland of the Cathaysia Block or the Hainan Uplift. A recent study of detrital zircons from the Cretaceous strata on Hainan Island yielded a major age at ca. $155 \mathrm{Ma}$, an age close to the peak observed in the samples [56]. The Cretaceous zircons in sample L15-1 displayed little variation in $\varepsilon_{\mathrm{Hf}}(\mathrm{t})$ values (most in -10 to 0 ), suggesting that they were formed from the remelting of the ancient crust, which was consistent with the $\varepsilon_{\mathrm{Hf}}(\mathrm{t})$ values observed in Hainan Island work (Figure 5).

The Permian to Triassic zircon grains, which had age peaks around $243 \mathrm{Ma}$ (Figure 4), match known exposures of the Indosinian igneous (and metamorphic) activity in the different source terranes. The Permian to Triassic granitic rocks is widely distributed in the Indochina Block and South China Block [49,57], with dated zircon U-Pb ages mainly concentrated between 280 to $220 \mathrm{Ma}$ (Figure 6), making specific matching of these peaks difficult. The age peaks of 408 and $432 \mathrm{Ma}$ in the samples are indicative of sources in the Yangtze and Indochina blocks. The zircons had negative $\varepsilon_{H f}(t)$ values, suggesting that they originated from the ancient crust. These age ranges are rarely reported in the Hainan Uplift (Figure 6B) and thus the sources may be the Red River region and central Vietnam. Although the zircons with $\varepsilon_{\mathrm{Hf}}(\mathrm{t})$ values $\leq 10$ fell within the ranges of both the Red River system and drainage systems in the central Vietnamese rivers, other zircons with $\varepsilon_{\mathrm{Hf}}(\mathrm{t})$ values $\geq 5$ were more consistent with the Red River (Figure 5), implying that these grains might be derived mainly from the 
source of the Red River, although there is a lack of zircons with $\varepsilon_{\mathrm{Hf}}(\mathrm{t})$ positive values $(>10)$ sampled in those terranes.

Neoproterozoic age groups with age peaks at ca. $748 \mathrm{Ma}, 787 \mathrm{Ma}$, and $966 \mathrm{Ma}$ were similar to those observed in the Southern Yangtze Block and the Red River (Figure 6A,D). In addition, the drainage systems in central Vietnam could have also provided a small amount of the Neoproterozoic-aged zircon grains (963 Ma) (Figure 6F). The zircons with age population between 800 and $700 \mathrm{Ma}$ in the S1 and S2 samples displayed a wide range of $\varepsilon_{\mathrm{Hf}}(\mathrm{t})$ values (Figure 5), which are consistent with the modern Red River system. The Neoarchean to Paleoproterozoic ages can account for a small part of the total ages, which can be regarded as the basement of the Yangtze and Indochina blocks and eroded from the granitic rocks or recycled from the sedimentary rocks that had previously formed. A recent study indicated that the Neoarchean and Paleoproterozoic K-rich granites in the Phan Si Pan Complex of north Vietnam yielded zircon U-Pb ages of 2.85 to $1.86 \mathrm{Ga}$ [58], which may also provide the detritus to the basin through the Red River system. The Precambrian zircons had variable $\varepsilon_{\mathrm{Hf}}(\mathrm{t})$ values, ranging from negative to positive (Figure 5), indicating that they were formed by both a juvenile source and the remelting of ancient crust. These zircons basically fall within the range of the Red River system, representing the important influence of Red River on sediments.

To examine the degrees of similarity among zircon U-Pb ages, the newly developed Multi-Dimensional Scaling (MDS) plots were used to compare the genetic relationships between samples and source terranes. The MDS plot based on the Kolmogorov-Smirnov (K-S) statistical method [59] is a dissimilarity matrix that constructs a map on which similar samples cluster closely together and dissimilar samples plot far apart [60]. In the MDS plots (Figure 7), the early Miocene samples showed a distinct affinity with the source terrane and also the drainage systems. The samples close to Hainan (L15-1 and QSYA) generally showed a greater affinity with the bedrock and rivers in Hainan, suggesting that the sediments were primarily derived from nearby sources (Figure 8). By contrast, samples S1 and S2 in this study plot were relatively far from Hainan (Figure 7A) but close to both rivers in central Vietnam and the Red River, indicating that they had an affinity with these drainage systems. However, compared with the bedrock, the affinity of these two samples with the southern Yangtze Block was greater than that of the Indochina Block, suggesting a major contribution from the southern Yangtze Block and a small contribution from the eastern Indochina Block (Figure 8).
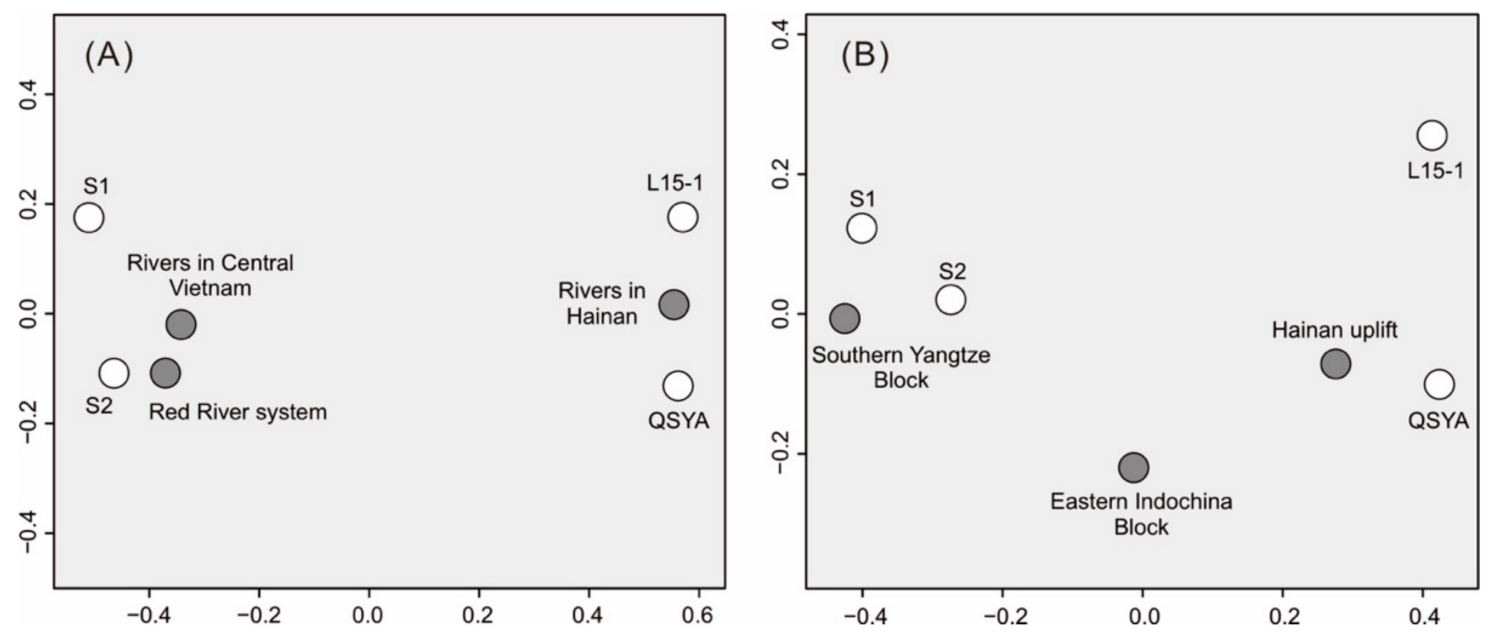

Figure 7. Multi-dimensional scaling plots using Kolmogorov-Smirnov (K-S) statistic for detrital zircon $\mathrm{U}-\mathrm{Pb}$ data $[59,60]$. The plots show the relationships between the core samples with regard to (A) the major drainage systems as defined from river sands and (B) potential source terranes around the Yinggehai-Song Hong Basin sampled from the outcrop. Axes are in dimensionless "K-S units" of distance between samples. Samples QSYA and L15-1 are from Yan et al. (2011) [13] and Wang et al. (2019) [26], respectively. 


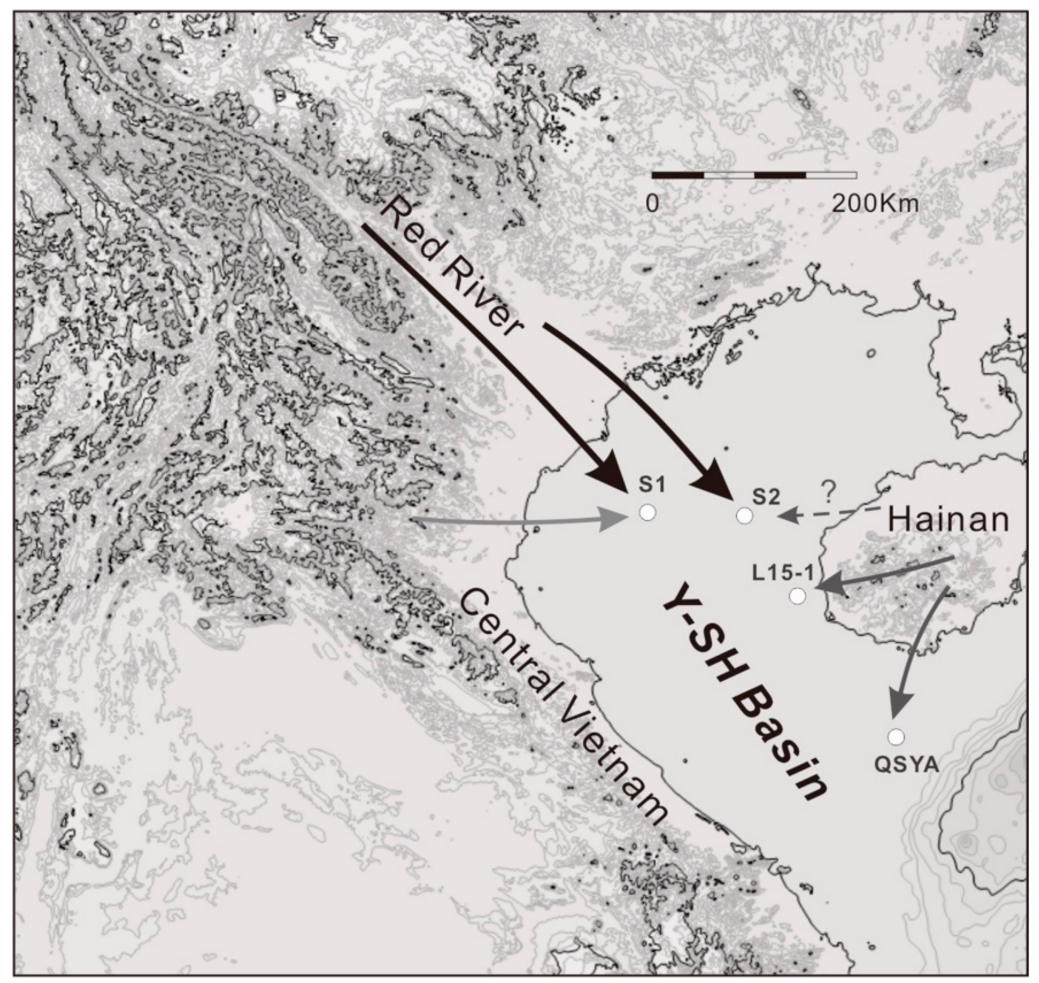

Figure 8. Provenance and possible transport pathways of the early Miocene sediments in the Yinggehai-Song Hong Basin. The arrows indicate the possible direction of the supplied sources.

In summary, detrital zircon $\mathrm{U}-\mathrm{Pb}$ ages from the lower Miocene Sanya Formation suggest that the sediments in this study were derived from multiple source terranes (Figure 8). The southern Yangtze Block played an important role in contributing detritus to the northern Y-SH Basin, and the eastern Indochina Block may also have a minor influence in this region. By contrast, the Hainan Uplift is a proximal source, which apparently had limited influence on the northern Y-SH Basin; it dominates eastern samples only.

\subsection{Provenance Variations in the Miocene}

Detrital zircon geochronological data presented here are suggestive of spatial variation in provenance in the early Miocene, which was primarily controlled by the location and distance of the source terranes. In order to characterize the variations in the provenance through time, from the early to middle Miocene sediments, these data were compared with published data of the middle Miocene sediments in the boreholes (L20 and H29, Figure 1) [27] at the northern basin, and were examined to understand temporal changes in provenance (Figure 9). The zircon age distributions for the lower to middle Miocene sediments were diverse, with some slight changes appearing in the proportions of the different age groups (Figure 9).

Samples in the Lingao uplift of the Y-SH Basin showed a range of age populations (Figure 9A-C), which may reflect the changing source terranes that supplied the sample location. The early Miocene sample in this study was more diverse than the middle Miocene samples, especially for ages older than $1800 \mathrm{Ma}$ (Figure 9C). Thus, sediments contained more Paleoproterozoic sources, which might be derived from the coeval magmatic rocks or recycled from the sedimentary rocks in the source region. The older Neoproterozoic zircon grains in samples L20-3 and S1-1, which showed a similar characteristic to the drainage systems in central Vietnam, suggested a possible contribution originating from the eastern Indochina Block. By contrast, the middle Miocene (13.8-10.5 Ma) showed more Silurian and less Early Triassic ages (Figure 9A), which was more similar to the Red River system, and revealed that the sample was primarily derived from the southern Yangtze Block. 


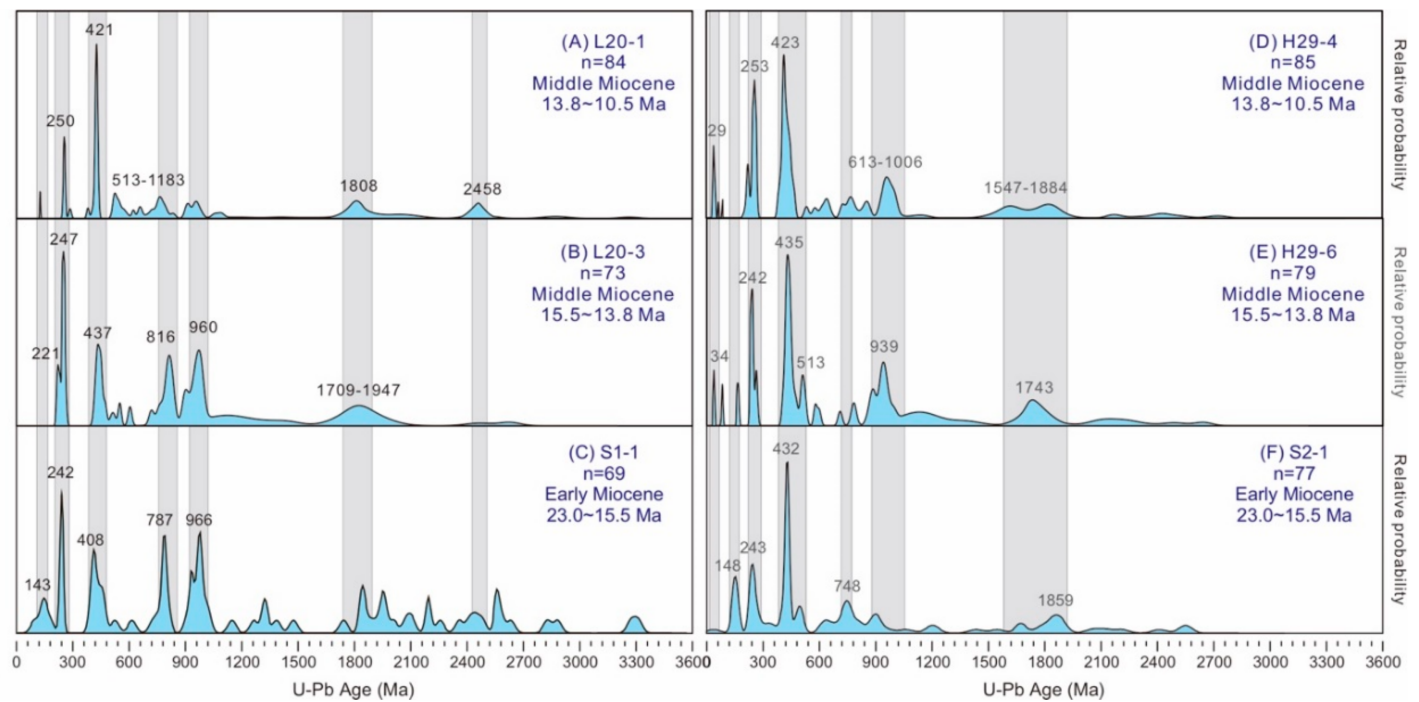

Figure 9. Detrital zircon $\mathrm{U}-\mathrm{Pb}$ age characteristics of the early-middle Miocene sediments in the Yinggehai-Song Hong Basin (A-F). The borehole L20 is located in the Lingao area and H29 is located in the Haikou area of the northern Y-SH Basin (Figure 1). Detailed sampling information of L20-1, L20-3, H29-4, and H29-6 can be found in the reference by Wang et al. (2016) [27].

Samples in the Haikou area of the Y-SH Basin displayed a similar age spectrum from the early to middle Miocene (Figure 9D-F), indicating that a relatively stable provenance was supplied in this sedimentary period. In spite of this, there was still variation in provenance at different geological periods. Compared with the early Miocene (23.0-15.5 Ma) (Figure 9F), samples of the middle Miocene (15.5-10.5 Ma) (Figure 9D,E) showed similar age distributions, which differed from the early Miocene sample by minor age peaks at ca. 29-34 Ma, and may thus represent an increased supply from the Red River Fault Zone after the early Miocene. The Neoproterozoic grains in the middle Miocene $(>900 \mathrm{Ma})$ were older than those in the early Miocene (748 Ma), suggesting a different source for the Neoproterozoic rocks. In addition, middle Miocene samples were absent in the Late Jurassic age population as well as in the early Miocene sample (148 Ma), implying that there was no influence from the Hainan or the hinterland Cathaysia Block in the middle Miocene.

Overall, the study of detrital zircon U-Pb ages revealed that there were no dramatic changes during the early to middle Miocene in the northern Y-SH Basin, suggesting that this was a relatively variational source supply at the time. Slight variation in detrital zircon and provenance was probably related to the amount of detritus materials inputted from central Vietnam, and may also be influenced by the evolution of the Red River system [23,61].

\section{Conclusions}

The following conclusions have been made based on the new dataset of U-Pb dating and Lu-Hf isotopes for detrital zircons from the lower Miocene Sanya Formation in the Y-SH Basin in the northwestern South China Sea.

(1) Detrital zircons analyzed in this study revealed several age clusters at ca. 148-143 Ma, 243-242 Ma, 432-408 Ma, 787-748 Ma, $966 \mathrm{Ma}$, and $1859 \mathrm{Ma}$. These zircon grains showed sub-rounded or rounded corners, implying prolonged or multi-cycle transport.

(2) The zircons had a broad range of ${ }^{176} \mathrm{Hf} /{ }^{177} \mathrm{Hf}$ ratios from 0.280773 to 0.282901 , with $\varepsilon_{\mathrm{Hf}}(\mathrm{t})$ values of -27.2 to +8.5 , suggesting that there were multiple sources for the sediments. Most of the zircon grains had negative $\varepsilon_{\mathrm{Hf}}(\mathrm{t})$ values, implying that the ancient crustal component was involved in the formation of zircon. Precambrian zircons were highly variable, with values ranging from negative to positive, indicating that they were formed by both a juvenile source and the remelting of ancient crust. 
(3) Based on comprehensive analyses of the results and previously published data, we confirmed that the Red River system was a dominant sediment contributor to the northern Yinggehai-Song Hong Basin during the early Miocene and that central Vietnam may also be a minor source terrane. The Hainan was the exclusive contributor controlling sediments in the eastern margin of the basin.

(4) This study showed that there was some variational source supply during the early to middle Miocene in the northern basin. The slight provenance variation depended on the amount of detritus materials inputted by central Vietnam, and may also be influenced by the evolution of the Red River system.

Supplementary Materials: The following are available online at http://www.mdpi.com/2075-163X/10/9/752/s1, Table S1: LAICPMS UPb dating data of zircons in this study; Table S2: LA-MC-ICP-MS Hf isotopic compositions of zircon in this study.

Author Contributions: Conceptualization, C.W. and X.L.; data curation, L.Z.; formal analysis, L.Z.; methodology, X.L.; project administration, M.S.; writing-original draft, C.W.; writing-review and editing, Y.L. and M.S. All authors have read and agreed to the published version of the manuscript.

Funding: This research was funded by the National Natural Science Foundation of China, grant number 41702115, the Guangdong Basic and Applied Basic Research Foundation, grant numbers 2017A030313250 and 2019A1515012017, the Fundamental Research Funds for the Central Universities, grant number $20 \operatorname{lgpy} 61$.

Acknowledgments: We appreciate L. Zhang and D. Wu for their assistance in sample analyses in GIGCAS. Thanks to China National Offshore Oil Corporation Ltd., Zhanjiang, China, for supplying the borehole samples. We wish to thank the editors Wilfried Winkler and Albrecht von Quadt and the four anonymous reviewers for their helpful comments and constructive suggestions.

Conflicts of Interest: The authors declare no conflict of interest.

\section{References}

1. Liu, Z.; Zhao, Y.; Colin, C.; Stattegger, K.; Wiesner, M.G.; Huh, C.A.; Zhang, Y.; Li, X.; Sompongchaiyakul, P.; You, C.F. Source-to-sink transport processes of fluvial sediments in the South China Sea. Earth-Sci. Rev. 2016, 153, 238-273. [CrossRef]

2. Kuehl, S.A.; Alexander, C.R.; Blair, N.E.; Harris, C.K.; Marsaglia, K.M.; Ogston, A.S.; Orpin, A.R.; Roering, J.J.; Bever, A.J.; Bilderback, E.L. A source-to-sink perspective of the Waipaoa River margin. Earth-Sci. Rev. 2016, 153, 301-334. [CrossRef]

3. Marsaglia, K.M.; DeVaughn, A.M.; James, D.E.; Marden, M. Provenance of fluvial terrace sediments within the Waipaoa sedimentary system and their importance to New Zealand source-to-sink studies. Mar. Geol. 2010, 270, 84-93. [CrossRef]

4. Fleming, E.J.; Flowerdew, M.J.; Smyth, H.R.; Scott, R.A.; Morton, A.C.; Omma, J.E.; Frei, D.; Whitehouse, M.J. Provenance of Triassic sandstones on the southwest Barents Shelf and the implication for sediment dispersal patterns in northwest Pangaea. Mar. Pet. Geol. 2016, 78, 516-535. [CrossRef]

5. Vincent, S.J.; Morton, A.C.; Hyden, F.; Fanning, M. Insights from petrography, mineralogy and U-Pb zircon geochronology into the provenance and reservoir potential of Cenozoic siliciclastic depositional systems supplying the northern margin of the Eastern Black Sea. Mar. Pet. Geol. 2013, 45, 331-348. [CrossRef]

6. Parra, J.G.; Marsaglia, K.M.; Rivera, K.S.; Dawson, S.T.; Walsh, J.P. Provenance of sand on the Poverty Bay shelf, the link between source and sink sectors of the Waipaoa River sedimentary system. Sediment. Geol. 2012, 280, 208-233. [CrossRef]

7. Warrick, J.A.; Bountry, J.A.; East, A.E.; Magirl, C.S.; Randle, T.J.; Gelfenbaum, G.; Ritchie, A.C.; Pess, G.R.; Leung, V.; Duda, J.J. Large-scale dam removal on the Elwha River, Washington, USA: Source-to-sink sediment budget and synthesis. Geomorphol. 2015, 246, 729-750. [CrossRef]

8. Carter, L.; Orpin, A.R.; Kuehl, S.A. From mountain source to ocean sink-The passage of sediment across an active margin, Waipaoa Sedimentary System, New Zealand. Mar. Geol. 2010, 270, 1-10. [CrossRef]

9. Carrapa, B. Resolving tectonic problems by dating detrital minerals. Geology 2010, 38, 191-192. [CrossRef]

10. Avigad, D.; Morag, N.; Abbo, A.; Gerdes, A. Detrital rutile U-Pb perspective on the origin of the great Cambro-Ordovician sandstone of North Gondwana and its linkage to orogeny. Gondwana Res. 2017. [CrossRef] 
11. Mason, C.C.; Fildani, A.; Gerber, T.; Blum, M.D.; Clark, J.D.; Dykstra, M. Climatic and anthropogenic influences on sediment mixing in the Mississippi source-to-sink system using detrital zircons: Late Pleistocene to recent. Earth Planet. Sci. Lett. 2017, 466, 70-79. [CrossRef]

12. Sevastjanova, I.; Clements, B.; Hall, R.; Belousova, E.A.; Griffin, W.L.; Pearson, N. Granitic magmatism, basement ages, and provenance indicators in the Malay Peninsula: Insights from detrital zircon $\mathrm{U}-\mathrm{Pb}$ and Hf-isotope data. Gondwana Res. 2011, 19, 1024-1039. [CrossRef]

13. Yan, Y.; Carter, A.; Palk, C.; Brichau, S.; Hu, X. Understanding sedimentation in the Song Hong-Yinggehai Basin, South China Sea. Geochem. Geophys. Geosyst. 2011, 12, Q06014. [CrossRef]

14. Wang, C.; Liang, X.; Xie, Y.; Tong, C.; Pei, J.; Zhou, Y.; Jiang, Y.; Fu, J.; Dong, C.; Liu, P. Provenance of Upper Miocene to Quaternary Sediments in the Yinggehai-Song Hong Basin, South China Sea: Evidence from Detrital Zircon U-Pb ages. Mar. Geol. 2014, 355, 202-217. [CrossRef]

15. Jiang, T.; Cao, L.; Xie, X.; Wang, Z.; Li, X.; Zhang, Y.; Zhang, D.; Sun, H. Insights from heavy minerals and zircon $\mathrm{U}-\mathrm{Pb}$ ages into the middle Miocene-Pliocene provenance evolution of the Yinggehai Basin, northwestern South China Sea. Sediment. Geol. 2015, 327, 32-42. [CrossRef]

16. Zhao, M.; Shao, L.; Liang, J.; Li, Q. No Red River capture since the late Oligocene: Geochemical evidence from the Northwestern South China Sea. Deep Sea Res. Part II Top. Stud. Oceanogr. 2015, 122, 185-194. [CrossRef]

17. Fyhn, M.B.W.; Thomsen, T.B.; Keulen, N.; Knudsen, C.; Rizzi, M.; Bojesen-Koefoed, J.; Olivarius, M.; Tri, T.V.; Phach, P.V.; Minh, N.Q.; et al. Detrital zircon ages and heavy mineral composition along the Gulf of Tonkin-Implication for sand provenance in the Yinggehai-Song Hong and Qiongdongnan basins. Mar. Pet. Geol. 2019, 101, 162-179. [CrossRef]

18. Clift, P.D.; Sun, Z. The sedimentary and tectonic evolution of the Yinggehai-Song Hong basin and the southern Hainan margin, South China Sea: Implications for Tibetan uplift and monsoon intensification. J. Geophys. Res. Solid Earth 2006, 111, B06405. [CrossRef]

19. Huang, B.; Xiao, X.; Li, X. Geochemistry and origins of natural gases in the Yinggehai and Qiongdongnan basins, offshore South China Sea. Org. Geochem. 2003, 34, 1009-1025. [CrossRef]

20. Wang, C.; Liang, X.; Foster, D.A.; Tong, C.; Liu, P.; Liang, X.; Zhang, L. Linking source and sink: Detrital zircon provenance record of drainage systems in Vietnam and the Yinggehai-Song Hong Basin, South China Sea. GSA Bull. 2018, 131, 191-204. [CrossRef]

21. Wang, C.; Wen, S.; Liang, X.; Shi, H.; Liang, X. Detrital zircon provenance record of the Oligocene Zhuhai Formation in the Pearl River Mouth Basin, northern South China Sea. Mar. Pet. Geol. 2018, 98, 448-461. [CrossRef]

22. Cao, L.; Jiang, T.; Wang, Z.; Zhang, Y.; Sun, H. Provenance of Upper Miocene sediments in the Yinggehai and Qiongdongnan basins, northwestern South China Sea: Evidence from REE, heavy minerals and zircon U-Pb ages. Mar. Geol. 2015, 361, 136-146. [CrossRef]

23. Van Hoang, L.; Wu, F.; Clift, P.D.; Wysocka, A.; Swierczewska, A. Evaluating the evolution of the Red River system based on in situ U-Pb dating and Hf isotope analysis of zircons. Geochem. Geophys. Geosyst. 2009, 10, Q11008. [CrossRef]

24. Wang, C.; Liang, X.; Zhou, Y.; Fu, J.; Jiang, Y.; Dong, C.; Xie, Y.; Tong, C.; Pei, J.; Liu, P. Construction of age frequencies of provenances on the eastern side of the Yinggehai Basin: Studies of LA-ICP-MS U-Pb ages of detrital zircons from six modern rivers, western Hainan, China. Earth Sci. Front. 2015, 22, 277-289. [CrossRef]

25. Jonell, T.N.; Clift, P.D.; Hoang, L.V.; Hoang, T.; Carter, A.; Wittmann, H.; Böning, P.; Pahnke, K.; Rittenour, T. Controls on erosion patterns and sediment transport in a monsoonal, tectonically quiescent drainage, Song Gianh, central Vietnam. Basin Res. 2017, 29, 659-683. [CrossRef]

26. Wang, C.; Liang, X.; Foster, D.A.; Liang, X.; Tong, C.; Liu, P. Detrital zircon ages: A key to unraveling provenance variations in the eastern Yinggehai-Song Hong Basin, South China Sea. Am. Assoc. Pet. Geol. Bull. 2019, 103, 1525-1552. [CrossRef]

27. Wang, C.; Liang, X.; Foster, D.A.; Xie, Y.; Tong, C.; Pei, J.; Fu, J.; Jiang, Y.; Dong, C.; Zhou, Y.; et al. Zircon $\mathrm{U}-\mathrm{Pb}$ geochronology and heavy mineral composition constraints on the provenance of the middle Miocene deep-water reservoir sedimentary rocks in the Yinggehai-Song Hong Basin, South China Sea. Mar. Pet. Geol. 2016, 77, 819-834. [CrossRef]

28. Liu, Y.; Gao, S.; Hu, Z.; Gao, C.; Zong, K.; Wang, D. Continental and oceanic crust recycling-induced melt-peridotite interactions in the Trans-North China Orogen: U-Pb dating, Hf isotopes and trace elements in zircons from mantle xenoliths. J. Petrol. 2010, 51, 537-571. [CrossRef] 
29. Zhang, L.; Ren, Z.-Y.; Xia, X.-P.; Wang, C.; Qian, S.-P. An improved U-Pb age dating method for detrital zircon by LA-MC-ICP-MS. Geochem. J. 2018, 52, 433-439. [CrossRef]

30. Andersen, T. Detrital zircons as tracers of sedimentary provenance: Limiting conditions from statistics and numerical simulation. Chem. Geol. 2005, 216, 249-270. [CrossRef]

31. Blichert-Toft, J.; Albarède, F. The Lu-Hf isotope geochemistry of chondrites and the evolution of the mantle-crust system. Earth Planet. Sci. Lett. 1997, 148, 243-258. [CrossRef]

32. Scherer, E. Calibration of the Lutetium-Hafnium Clock. Science 2001, 293, 683-687. [CrossRef] [PubMed]

33. Griffin, W.L.; Wang, X.; Jackson, S.E.; Pearson, N.J.; O’Reilly, S.Y.; Xu, X.; Zhou, X. Zircon chemistry and magma mixing, SE China: In-situ analysis of Hf isotopes, Tonglu and Pingtan igneous complexes. Lithos 2002, 61, 237-269. [CrossRef]

34. Vermeesch, P. IsoplotR: A free and open toolbox for geochronology. Geosci. Front. 2018, 9, 1479-1493. [CrossRef]

35. Vermeesch, P. On the visualisation of detrital age distributions. Chem. Geol. 2012, 312-313, 190-194. [CrossRef]

36. Wu, Y.; Zheng, Y. Genesis of zircon and its constraints on interpretation of U-Pb age. Chinese Sci. Bull. 2004, 49, 1554-1569. [CrossRef]

37. Wen, S. Geochronologic and Geochemical Studies of Permian-Triassic Magmatism in Hainan Island, South China. Ph.D. Thesis, University of Chinses Academy of Sciences, Beijing, China, 2013.

38. Wen, S.; Liang, X.; Fan, W.; Wang, Y.; Chi, G.; Liang, X.; Zhou, Y.; Jiang, Y. Zircon U-Pb ages, Hf isotopic composition of Zhizhong granitic intrusion in Ledong area of Hainan island and their tectonic implications. Geotecton. Metallog. 2013, 37, 294-307.

39. Sun, S.J.; Zhang, L.P.; Zhang, R.Q.; Ding, X.; Zhu, H.L.; Zhang, Z.F.; Sun, W.D. Mid-Late Cretaceous igneous activity in South China: The Qianjia example, Hainan Island. Int. Geol. Rev. 2018, 60, 1665-1683. [CrossRef]

40. Zheng, J.; Griffin, W.L.; O’Reilly, S.Y.; Zhang, M.; Pearson, N.; Pan, Y. Widespread Archean basement beneath the Yangtze craton. Geology 2006, 34, 417-420. [CrossRef]

41. Zhao, X.F.; Zhou, M.F.; Li, J.W.; Sun, M.; Gao, J.F.; Sun, W.H.; Yang, J.H. Late Paleoproterozoic to early Mesoproterozoic Dongchuan Group in Yunnan, SW China: Implications for tectonic evolution of the Yangtze Block. Precambrian Res. 2010, 182, 57-69. [CrossRef]

42. Peng, M.; Wu, Y.; Gao, S.; Zhang, H.; Wang, J.; Liu, X.; Gong, H.; Zhou, L.; Hu, Z.; Liu, Y.; et al. Geochemistry, zircon $\mathrm{U}-\mathrm{Pb}$ age and $\mathrm{Hf}$ isotope compositions of Paleoproterozoic aluminous A-type granites from the Kongling terrain, Yangtze Block: Constraints on petrogenesis and geologic implications. Gondwana Res. 2012, 22, 140-151. [CrossRef]

43. Zhou, M.F.; Yan, D.P.; Kennedy, A.K.; Li, Y.; Ding, J. SHRIMP U-Pb zircon geochronological and geochemical evidence for Neoproterozoic arc-magmatism along the western margin of the Yangtze Block, South China. Earth Planet. Sci. Lett. 2002, 196, 51-67. [CrossRef]

44. Wu, R.X.; Zheng, Y.F.; Wu, Y.B.; Zhao, Z.F.; Zhang, S.B.; Liu, X.; Wu, F.Y. Reworking of juvenile crust: Element and isotope evidence from Neoproterozoic granodiorite in South China. Precambrian Res. 2006, 146, 179-212. [CrossRef]

45. Zhang, L.S.; Schärer, U. Age and origin of magmatism along the Cenozoic Red River shear belt, China. Contrib. Mineral. Petrol. 1999, 134, 67-85. [CrossRef]

46. Xu, D.R.; Xia, B.; Li, P.C.; Chen, G.H.; Ma, C.; Zhang, Y.Q. Protolith natures and U-Pb sensitive high mass-resolution ion microprobe (SHRIMP) zircon ages of the metabasites in Hainan Island, South China: Implications for geodynamic evolution since the late Precambrian. Isl. Arc 2007, 16, 575-597. [CrossRef]

47. Li, Z.X.; Li, X.H.; Li, W.X.; Ding, S. Was Cathaysia part of Proterozoic Laurentia?-New data from Hainan Island, South China. Terra Nov. 2008, 20, 154-164. [CrossRef]

48. Zhou, Y.; Liang, X.; Kröner, A.; Cai, Y.; Shao, T.; Wen, S.; Jiang, Y.; Fu, J.; Wang, C.; Dong, C. Late Cretaceous lithospheric extension in SE China: Constraints from volcanic rocks in Hainan Island. Lithos 2015, 232, 100-110. [CrossRef]

49. Faure, M.; Nguyen, V.V.; Hoai, L.T.T.; Lepvrier, C. Early Paleozoic or Early-Middle Triassic collision between the South China and Indochina Blocks: The controversy resolved? Structural insights from the Kon Tum massif (Central Vietnam). J. Asian Earth Sci. 2018, 166, 162-180. [CrossRef]

50. Van Tran, T.; Faure, M.; Van Nguyen, V.; Bui, H.H.; Fyhn, M.B.W.; Nguyen, T.Q.; Lepvrier, C.; Thomsen, T.B.; Tani, K.; Charusiri, P. Neoproterozoic to Early Triassic tectono-stratigraphic evolution of Indochina and adjacent areas: A review with new data. J. Asian Earth Sci. 2020, 191, 104231. [CrossRef] 
51. Liu, J.; Tran, M.-D.; Tang, Y.; Nguyen, Q.-L.; Tran, T.-H.; Wu, W.; Chen, J.; Zhang, Z.; Zhao, Z. Permo-Triassic granitoids in the northern part of the Truong Son belt, NW Vietnam: Geochronology, geochemistry and tectonic implications. Gondwana Res. 2012, 22, 628-644. [CrossRef]

52. Shi, M.F.; Lin, F.C.; Fan, W.Y.; Deng, Q.; Cong, F.; Tran, M.D.; Zhu, H.P.; Wang, H. Zircon U-Pb ages and geochemistry of granitoids in the Truong Son terrane, Vietnam: Tectonic and metallogenic implications. J. Asian Earth Sci. 2015, 101, 101-120. [CrossRef]

53. Hieu, P.T.; Yang, Y.Z.; Binh, D.Q.; Nguyen, T.B.T.; Dung, L.T.; Chen, F. Late Permian to Early Triassic crustal evolution of the Kontum massif, central Vietnam: Zircon U-Pb ages and geochemical and Nd-Hf isotopic composition of the Hai Van granitoid complex. Int. Geol. Rev. 2015. [CrossRef]

54. Gilley, L.D.; Harrison, T.M.; Leloup, P.H.; Ryerson, F.J.; Lovera, O.M.; Wang, J.-H. Direct dating of left-lateral deformation along the Red River shear zone, China and Vietnam. J. Geophys. Res. Solid Earth 2003, 108, 2127. [CrossRef]

55. Xu, Y.; Wang, C.Y.; Zhao, T. Using detrital zircons from river sands to constrain major tectono-thermal events of the Cathaysia Block, SE China. J. Asian Earth Sci. 2016, 124, 1-13. [CrossRef]

56. Jiang, X.Y.; Li, X.H.; Collins, W.J.; Huang, H.Q. U-Pb age and Hf-O isotopes of detrital zircons from Hainan Island: Implications for Mesozoic subduction models. Lithos 2015, 239, 60-70. [CrossRef]

57. Li, J.; Zhang, Y.; Zhao, G.; Johnston, S.T.; Dong, S.; Koppers, A.; Miggins, D.P.; Sun, H.; Wang, W.; Xin, Y. New insights into Phanerozoic tectonics of South China: Early Paleozoic sinistral and Triassic dextral transpression in the east Wuyishan and Chencai domains, NE Cathaysia. Tectonics 2017, 36, 819-853. [CrossRef]

58. Zhao, T.; Cawood, P.A.; Wang, K.; Zi, J.W.; Feng, Q.; Nguyen, Q.M.; Tran, D.M. Neoarchean and Paleoproterozoic K-rich granites in the Phan Si Pan Complex, north Vietnam: Constraints on the early crustal evolution of the Yangtze Block. Precambrian Res. 2019, 332, 105395. [CrossRef]

59. Kruskal, J.B. Multidimensional scaling by optimizing goodness of fit to a nonmetric hypothesis. Psychometrika 1964, 29, 1-27. [CrossRef]

60. Vermeesch, P. Multi-sample comparison of detrital age distributions. Chem. Geol. 2013, 341, 140-146. [CrossRef]

61. Wang, C.; Liang, X.; Foster, D.A.; Liang, X.; Zhang, L.; Su, M. Provenance and drainage evolution of the Red River revealed by $\mathrm{Pb}$ isotopic analysis of detrital K-feldspar. Geophys. Res. Lett. 2019, 46, 6415-6424. [CrossRef] 